\title{
A Cell Line Derived from Early Embryos of Rose Bitterling (Teleostei: Cypriniformes: Acheilognathinae)
}

\author{
Takayoshi Ueda ${ }^{1}$ \\ ${ }^{1}$ Faculty of Education, Utsunomiya University, Utsunomiya, Japan \\ Correspondence: Takayoshi Ueda, Faculty of Education, Utsunomiya University, Utsunomiya, Japan. E-mail: \\ ueda@cc.utsunomiya-u.ac.jp
}

Received: September 9, 2016

Accepted: September 15, $2016 \quad$ Online Published: September 15, 2016

doi:10.5539/enrr.v6n3p116

URL: http://dx.doi.org/10.5539/enrr.v6n3p116

\begin{abstract}
A cell line was established from embryo cells of rose bitterling Rhodeus ocellatus ocellatus (Teleostei: Acheilognathinae). This cell line is maintained for more than seven years in my laboratory. Karyotype in it does not have the change either. In maintenance of the biological diversity, it is an important problem to demand a method to prevent the extinction of the species. This cell line will become the clue of the study of the embryonic stem cell in endangered species. On the other hand, this cell line which karyotype is stable in its will be a useful tool for a mutagenicity assay.
\end{abstract}

Keywords: environmental preservation, endangered species, embryonic cell line, bitterlings

\section{Introduction}

It is important that biological diversity is kept to maintain healthy environment. In maintenance of the biological diversity, it is an important problem to demand a method to prevent the extinction of the species. Bitterlings are freshwater fish species ascribed to the subfamily Acheilognathinae (Cyprinidae), and are distributed throughout Eurasia. Three valid genera, Acheilognathus, Rhodeus, and Tanakia (Arai \& Akai, 1988), grouping approximately 80 species/subspecies (Froese \& Pauly, 2013), have been recognized.

Eighteen species/subspecies of bitterlings, including two natural treasures, namely A. longipinnis and T. tanago, are distributed in Japan. Most of them are on the verge of extinction, and the conservation of them is matter of great urgency. The preservation of the whole ecosystem is an ideal way. But, the artificial conservation of genetic resources, namely artificial breeding, cryopreservation of sperms or embryonic cells, and others, would be needed. Though embryonic stem cells should be as a useful material for the conservation of genetic resources, there are extremely few examples of these cell line in fish. And, there is not a report in bitterlings at all.

A cell line, without the change in a karyotype, was established from early embryos of $R$. ocellatus ocellatus, and this cell line is maintained for more than seven years in my laboratory.

\section{Materials and Methods}

\subsection{Medium}

Composition of the basic culture medium was "Eagle MEM $+10 \%$ fetal bovine serum $+100 \mathrm{IU}$ penicillin + $15 \mathrm{mM}$ HEPES (adjusted to $\mathrm{pH} 7$ with $\mathrm{NaHCO}_{3}$ )". And, the used medium which filtered the liquid which cultured the catfish (Silurus asotus) cell that an increase was prosperous for three days was prepared. At the present study, the compound medium which mixed the basic and the used medium at 1:1 was used.

\subsection{Primary Culture}

The surface of the egg at the molula - blastula stage was sterilized by immersion in sodium hypochrolide (1\%) for $60 \mathrm{~s}$ at $4-10^{\circ} \mathrm{C}$. After washing twice, 15 embryos, without chorion and the yolk, were cultured in a plastic flask (Corning $\mathrm{Co}, 25 \mathrm{~cm}^{2}$ ) with $4 \mathrm{ml}$ of medium at $20^{\circ} \mathrm{C}$. Half of the medium was changed every $7-10$ days.

\subsection{Subculture}

Cells multiplied from the circumference of the lump of embryo cells which adhered to the base. After cells covered in the whole base exhaustively, they were divided into about half. Cells were needed approximately eight months to subculturing it in a beginning. After the first subculture, cells were subcultured every 3-4 weeks. 


\subsection{Chromosome Preparation}

At the third day from subculture, cells were treated with TN-16 $(0.1 \mu \mathrm{g} / \mathrm{ml}$ : 3-(1-Anilinoethylidene)-5-benzylpyrolidine-2, 4-dione, Wako Pure Chemical Ind.) for approximately $16 \mathrm{~h}$ to obtain more metaphases. Air-dried chromosome slides were made after hypotonic treatment with $0.5 \%$ Sodium Citrate for $5 \mathrm{~min}$, at $27^{\circ} \mathrm{C}$ and fixed with 3:1 ethanol-acetic acids, and then stained with the Giemsa solution.

\section{Results and Discussion}

R. ocellatus ocellatus showed 48 chromosomes (2n), consisting 28 metacentrics / submetacentrics and 20 subtelocentrics (Figure 1). The cells multiply with one level in the base of the flask (Figure 2). The shape does not have a change more than seven years. Karyotype does not have the change either (Figure 3). The increase of the cell is slow. But, More than 100 metaphases with good shaped chromosomes are possible to observe from one flask. On the chromosome preparation, effect was too strong by the processing in general with $\mathrm{KCl}$. Processing with the Sodium Citrate was moderate. The pluripotency of this cell is unclear at present.

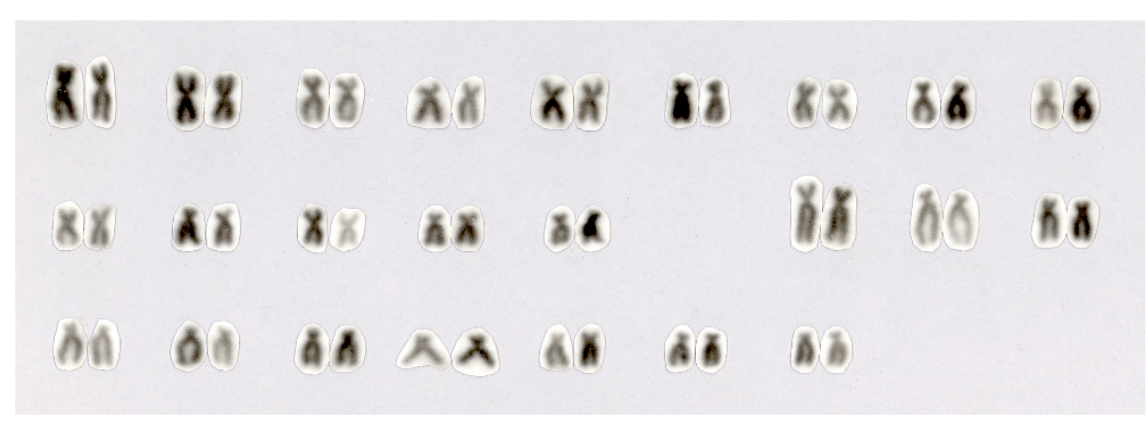

Figure 1. Karyotype of rose bitterling Rhodeus ocellatus ocellatus

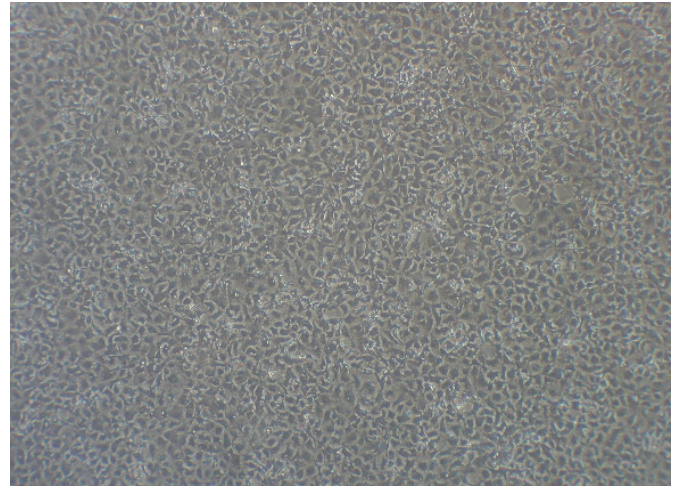

Figure 2. Shape of cells in the cell line

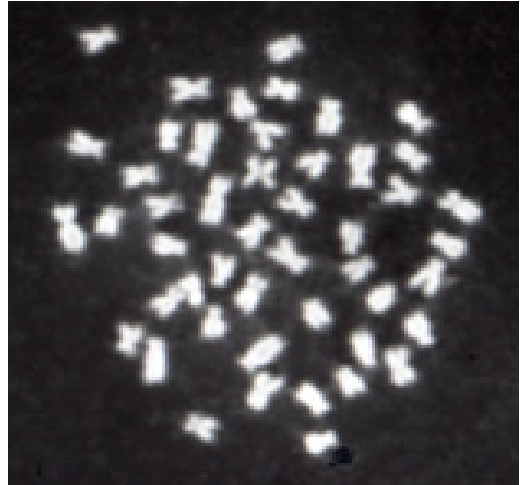

Figure 3. A metaphase figure from the cell line

Bitterlings have several characteristics that make it an excellent educational resource in science and environmental education. (1) The basic genetic mechanisms of the fish are similar to those of humans at the cellular and genetic level. Bitterlings aid in understanding the basic mechanisms of inheritance. (2) Additionally artificial feeding of bitterlings is simple. These fish have a unique ecology in that they lay their eggs in bivalves. Bitterlings, for reproduction in the wild, required an environment that supports freshwater bivalves. Environmental preservation of such an environment (the Satoyama) is an important issue; a study of bitterlings would provide a living example to grasp the biodiversity and ecosystems of this environmentally sensitive area. (3) Bitterlings illustrate the symbiosis between humans and nature, because the habitats of both bitterlings and bivalves are closely related to human activities.

Through the study using bitterlings as an educational resource, we would develop a better understanding of the importance of both bitterlings and Satoyama ecosystem. The accumulation of feelings generated in each person involved in the study will increase motivation and a growing awareness of environmental preservation. The study of bitterlings, will engender an understanding of the importance of biodiversity, leading to an appreciation 
of the natural area and culture of the region. The increase in awareness will lead to conservation of the natural habitat of bitterlings.

The mutagenicity assay plays an important role to evaluate the genotoxicity of chemicals and also to predict the carcinogenicity of chemicals. One of the major mutagenicity tests to assess the cytogenetic damage is the chromosomal aberration test using mammalian cells in vitro and in vivo micronucleus test. It is important to use fish and other aquatic organisms as experimental materials to monitor and to evaluate the degree of pollution of the water system, and to assess the effect on aquatic resources (Ueda et al., 1992; Hayashi et al., 1998; Ueda, Takase, \& Hayashi, 2004). This cell line that karyotype does not have the change will be useful for a mutagenicity assay.

For the conservation of endangered species, the understanding of their various biological properties is needed. It is hoped that embryonic stem cells greatly contribute to the elucidation of basic properties of the development, the differentiation, and others in fish, because they multiply in a culture dish. I want to proceed with the research dealing with embryonic stem cells, as important part of the study on bitterlings.

\section{References}

Arai, R., \& Akai, Y. (1988). Acheilognathus melanogaster, a senior synonym of A. moriokae, with a revision of the genera of the subfamily Acheilognathinae (Cypriniformes, Cyprinidae). Bull. Natl. Sci. Mus., Tokyo, (A), 14, 199-213.

Froese, R., \& Pauly, D. (2013). FishBase. Retrieved from http://www.fishbase.org/search.php

Hayashi, M., Ueda, T., Uyeno, K., Wada, K., Kinae, N., Saotome, K., ... Ojima, Y. (1998). Development of genotoxicity assay systems that use aquatic organisms. Mutat. Res., 399, 125-133.

Ueda, T., Hayashi, M., Ohtsuka, Y., Nakamura, T., Kobayashi, J., \& Sofuni, T. (1992). A preliminary study of the micronucleus test by acridine orange fluorescent staining compared with chromosomal aberration test using fish erythropoietic and embryonic cells. Wat. Sci. Tech., 25, 235-240.

Ueda, T., Takase, K., \& Hayashi, M. (2004). Methodological consideration of micronucleus test using zebrafish (Danio rerio). Bull. Fac. Educ. Utsunomiya Univ., 54, 5-15. (in Japanese with English abstract)

\section{Copyrights}

Copyright for this article is retained by the author(s), with first publication rights granted to the journal.

This is an open-access article distributed under the terms and conditions of the Creative Commons Attribution license (http://creativecommons.org/licenses/by/4.0/). 